\title{
A new naturalized plant in Korea: Carex molestiformis Reznicek and Rothrock (Cyperaceae)
}

\author{
Seungwon KO $\mathrm{K}^{\dagger}$, Sang Deog SHIM ${ }^{1 \dagger}$, Jong Young HYUN and Joo-Hwan KIM ${ }^{*}$ \\ Department of Life Science, Gachon University, Seongnam 13120, Korea \\ ${ }^{1}$ Woori Plant Research Institute, Gwangju 61431, Korea
}

(Received 22 May 2020; Revised 14 September 2020; Accepted 23 September 2020)

\begin{abstract}
We found an unrecorded species, Carex molestiformis Reznicek \& Rothrock, in Byeokparyeong, Daehwa-myeon, Pyeongchang-gun, Gangwon-do, South Korea. This species is native to southern parts of the United States (ca. 11 states, including Arkansas, Missouri, and Oklahoma). These plants are usually distributed densely in stream flood plains, bottomlands, stream banks, and along roadsides. Belonging to section Ovales Kunth, perennial herbs with gynecandrous spikes, $C$. molestiformis is closely related to $C$. maackii Maxim. and C. scoparia Willd. and is distinguished from them by the number (2-4) of spikes in each inflorescence and the width (2.6-3.4 mm) and number (6-9) of veins of perigynia. A new Korean name of C. molestiformis 'GaNeun-Ta-Rae-Sa-Cho' was given, as it has slender overall appearance compared with C. maackii (Ta-Rae-SaCho). We also provide a description, illustrations, photographs and a key of related taxa in Korea. We compared three DNA barcode region (chloroplast DNA $m a t K, n d h F$ and nuclear ribosomal DNA internal transcribed spacer) sequences from $C$. molestiformis with those of $C$. maackii and $C$. scoparia, determining eight speciesspecific single nucleotide polymorphism sites for C. molestiformis.
\end{abstract}

Keywords: unrecorded species, Carex molestiformis, sect. Ovales, Cyperaceae

Carex L. is one of the largest genera in vascular plants and comprised to over 2,000 species. Adapting to various climates, they are distributed worldwide except in limited parts of South Africa and South America (Reznicek, 1990).

Section Ovales Kunth, belongs to subgenus Vignea (P. Beauv. ex T. Lestib.) Peterm. This section is characterized by gynaecandrous spikes, winged perigynia (Reznicek., 1993) and includes about 90 species. Seventy-two species of sect. Ovales are distributed in North America (Mastrogiuseppe et al., 2002) and several species are endemic in Central America, Europe, Asia (Reznicek, 1993). Also 226 species of Carex are distributed in Korean Peninsula, but only two species among them are included in sect. Ovales (C. maackii Maxim and $C$. scoparia Willd) (Oh, 2006, Cheon et al., 2014).

In this study, we report Carex molestiformis Reznik \& Rothrock which was found firstly in Byeokparyeong, Pyeongchang-gun, Korea as an unrecorded naturalized plant.
Also, we provide its description, illustrations, photographs, and the key of related taxa in Korea. And we compared the morphological characters in detail with the most related species.

And we compared partial sequences of three DNA barcode regions (chloroplast DNA [cpDNA] matK, $n d h \mathrm{~F}$, and nuclear ribosomal DNA [nrDNA] internal transcribed spacer [ITS]) to show the nucleotide differences among $C$. molestiformis, $C$. maackii, and C. scoparia. And we discussed the possible introduction route $C$. molestiformis by comparision of the climates and growth condition in native area.

\section{Taxonomic Treatment}

Carex molestiformis Reznicek \& Rothrock, Contr. Univ. Michigan Herb. 21: 300, 1997.-Type: USA. South bank of Illinois River, just E of bridge for Okla. Hwy 59, ca. $1.5 \mathrm{mi}$ $\mathrm{N}$ of Watts, NE 1/4 section 18, T19N R26E, Adair County,

\footnotetext{
These authors contributed equally to this work.

*Author for correspondence: kimjh2009@gachon.ac.kr
} 

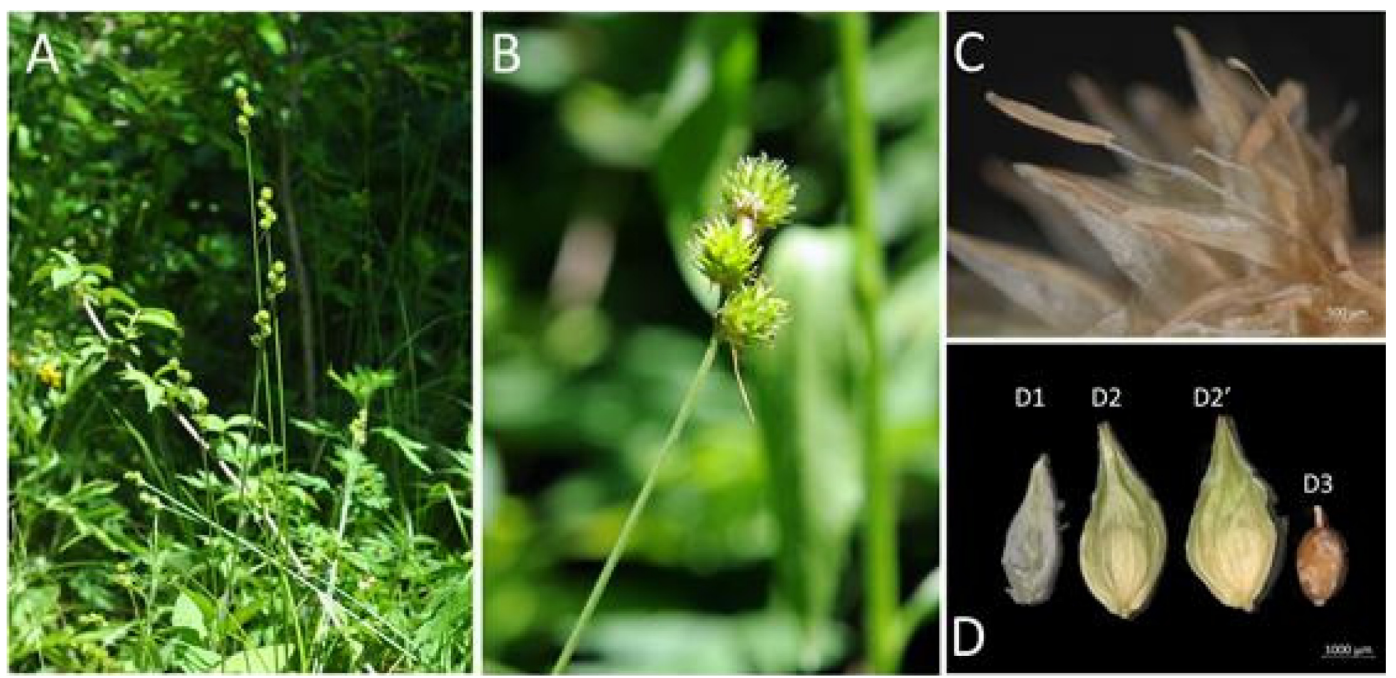

Fig. 1. Photographs of Carex molestiformis Reznik \& Rothrock. A. Habit. B. Inflorescence. C. Staminate flowers. D. Pistillate scale (D1), perigynium (Abaxial, D2), perigynium (Adaxial, D2'), and achene (D3).

Oklahoma, 26 May 1994, A. A. Reznicek 9777 \& S. A. Reznicek, S. D. Jones, G. D. Jones [holotype: MICH (in photo!); isotypes: DAO (in photo!), GH (in photo!), NY (in photo!), TEX (in photo!), WIS (in photo!)].

Plants Perennial. Cespitose in small clumps, Rhizomes short and woody. mature clumps covering grounds with creeping rhizomes. Culms 25-120 cm, trigonous, erect, smooth except scabrous just below inflorescence; Basal sheaths bladeless, medium to dark brown, disintegrating into short, dark brown fibers. Leaves $3-5$, on lower $1 / 5-2 / 5$ of the culm; blades $2.5-$ $32 \mathrm{~cm}$ long, 1.7-3.8 mm wide, plicate, glabrous or papillose adaxially, the margins and midrib antrorsely scabrous distally; leaf sheaths $1-10 \mathrm{~cm}$ long, tightly enveloping culms, smooth, yellow-green, the intervenal areas \pm white with scattered septa; the inner band of sheaths glabrous, its apex concave or truncate and reaching from the base of the blade to $1.5 \mathrm{~mm}$ above, light brown to whitish. Inflorescences 1.2-2.7(-3.4) cm long, apex of culms erect or rarely angled above the lowest spike, spikes overlapping or congested, the lowest spike 1.5-6(-9) $\mathrm{mm}$, spikes sessile, single at each node. Bracts inconspicuous, scalelike or setaceous, sheathless, $0.4-1.5 \mathrm{~cm}$ long, upper bracts reduced. Spikes 2-4(-5), gynaecandrous, globose to ovoid with rounded or tapered bases, 7-12 mm long, pistillate portion 6$10 \mathrm{~mm}$ long, 5-10 mm wide, (10-)15-40 flowered, staminate portion 1-5(-9.5) mm long, 1.2-2.5 mm wide, 6-14 flowered. Scales pale brown or yellow-green center and hyaline margins, pistillate scales usually reaching the base or sometimes the middle of the beak, 2.9-4 mm long, 1.1-1.6 mm wide, lanceovate, apex obtuse or acute, 1-nerved. staminate scales $2.6-5 \mathrm{~mm}$ long, 1.3-1.8 mm wide, ovate, apex obtuse or rarely acute, 1nerved; Perigynia 4-5.4(-6.1) mm long, (2.4-)2.6-3.4 mm wide, (1.3-)1.5-1.9 times as long as wide, appressedascending, plano-convex with broadly ovate, broadly elliptic, or orbicular body, 2.7-3.5 mm long, (0.9-)1-1.6 times as long as wide and 1.8-2.7 times as long as beak, widest 1.2-2 mm above base, broadly thin-winged, wing $0.3-0.8 \mathrm{~mm}$ wide, finely serrulate-margined except near base, gradually and symmetrically contracted into beak, deep green to brownish when overmatured, with paler margins, smooth, leathery, sessile, sharply (3-)4-7-nerved adaxially over achene, 6-9nerved abaxially over achene and 1-2-nerved in the winged margin; beaks 1.1-1.9 mm long, strongly flattened and serrulate-margined to apex, the apex bidentate with scabrousmargined teeth $0.1-0.5 \mathrm{~mm}$ long, distance from summit of achene to tip of beak 1.7-2.6(-2.9) mm long. Achenes 1.6-2 mm long, 1.4-1.8 mm wide, 1-1.3 times as long as wide, biconvex, broadly oval to orbicular, pale brown to brown, short-stipitate at base, apiculum $0.1-0.45 \mathrm{~mm}$ long; style straight; stigmas 2, Anthers 3, (1.4-)1.6-2.6 mm long.

Korean name: Ga-neun-ta-rae-sa-cho (가는타래사초).

Distribution: Southern and Central United States (Arkansas, Georgia, Kentucky, Mississippi, Missouri, North Carolina, Ohio, Oklahoma, Tennessee, Virginia, West Virginia) and Korea (Pyeongchang)

Specimens examined: KOREA. Gangwon-do: Pyeongchanggun, Daehwa-myeon, Byeokparyeong, 21 Jun 2018, Sang Deog Shim and Young Ho Jeon 18062101-18062104 (GCU); 12 Jul 2018, Sang Deog Shim and Young Ho Jeon 18071201-18071202 (GCU). Daegu: Dong-gu, Geumgang-dong, 833-40, 30 May 2018, 

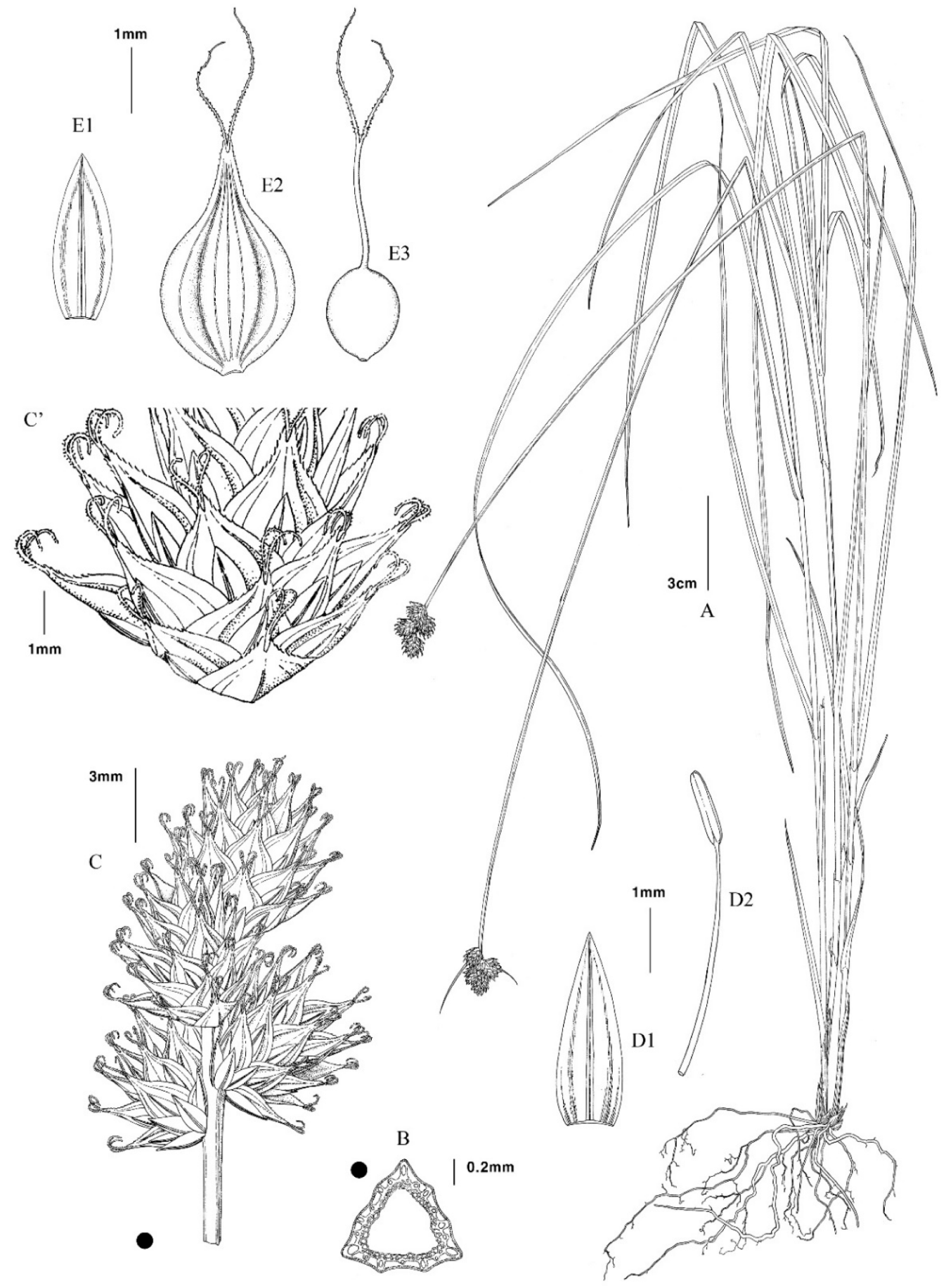

Fig. 2. Illustration of Carex molestiformis Reznik \& Rothrock. A. Whole plant. B. Cross section of culm. C. Inflorescence. C'. Lower portion of spike. D1. Staminate scale. D2. Stamen. E1. Pistillate scale. E2. Perigynium. E3. Achene.

Won-Jung Lee, Young-Ja Jeong and Young-Soon Lee DG18124 (KB). Gyeongsangbuk-do: Sangju-si, Jungdong-myeon, Hoesangri, 5 Jun 2016, J. H. Kim and J. H. Kim 163360 (KB).

USA. Grassy Creek, North Carolina, 31 May 2009, C. J. Rothfels \#2917 (MICH); Adair County, Oklahoma, 26 May
1994, S. A. Reznicek, A. A. Reznicek, S. D. Jones and G. D. Jones, \#9777 (BRIT); Washington County, 26 May 1994, A. A. Reznicek, S. A. Reznicek, S. D. Jones and G. D. Jones, \#9793 (DAO); Alleghany County, North Carolina, 15 Jun 2010, D. B. Poindexter 10-340 (NY). 
Table 1. Comparison of morphological characters between Carex scoparia and C. molestiformis.

\begin{tabular}{lcc}
\hline \hline \multicolumn{1}{c}{ Character } & C. scoparia & C. molestiformis \\
\hline Length of plant $(\mathrm{cm})$ & $20-100$ & $25-120$ \\
Length of leaf $(\mathrm{cm})$ & $10-35$ & $2.5-32$ \\
Apex of sheath & U-shaped & Concave or truncate \\
Cross section of culm & Trigonous & Ttrigonous \\
Length of inflorescence $(\mathrm{cm})$ & $1.5-6$ & $1.2-2.7$ \\
Length of spike $(\mathrm{mm})$ & $7-16$ & $7-12$ \\
Spikes in inflorescence & $3-10$ & $2-4$ \\
Color of pistillate scale & Hyaline brown with green or gold midstripe & Pale brown with yellow-green or pale brown midstripe \\
Length of pistillate scale $(\mathrm{mm})$ & $3.4-4$ & $2.9-4$ \\
Apex of pistillate scale & Acuminate & Obtuse or acute \\
Perigynium & Lanceolate & Broadly ovate, broadly elliptic or orbicular \\
Width of perigynium $(\mathrm{mm})$ & $1.2-2$ & $2.6-3.4$ \\
Color of perigynium & Golden brown & Deep green or brownish (overmature) \\
Veins in perigynium & 5 or less & $6-9$ \\
(abaxial over achene) & Ovate to elliptic & Oval to orbicular \\
Achene & $1.3-1.7$ & $1.6-2$ \\
Length of achene $(\mathrm{mm})$ & &
\end{tabular}

Notes: We collected a newly introduced plant in Byeokparyeong, Pyeongchang-gun, Korea. They grew in open space of sun-rich grassland. About 20 clumps were found in that area. Diameter of each clump has grown to $20-40 \mathrm{~cm}$. We identified it as $C$. molestiformis by using morphological characters such as culm, inflorescence, veins on perigynium. In native habitat, they are usually distributed throughout stream flood plains, bottomlands, stream banks.

The first character which could distinguish C. molestiformis from other taxa is type of inflorescence. It has gynaecandrous spikes and scalelike bracts, so it can be distinguished from species such as Carex neurocarpa Maxim. In Korea, there are two species (C. maackii and C. scoparia) in the same section. It is obviously different from anothers by the width of perigynium, number of spikes, veins of perigynium (Mastrogiuseppe et al. 2002; Cheon et al., 2014). The number of spikes in each inflorescence of $C$. molestiformis is less than 10 from that of $C$. maackii. And there are two diagnostic characters which are able to distinguish $C$. molestiformis from $C$. scoparia. The width of perigynium in $C$. molestiformis is 2.6 to $3.4 \mathrm{~mm}$, unlike in $C$. scoparia, 1.2 to $2 \mathrm{~mm}$. And the number of veins of perigynium in C. molestiformis is 6-9, but C. scoparia has only 5-veined perigynium. Also, we present the other morphological differences between $C$. molestiformis and $C$. scoparia (Cheon et al., 2014, Cho et al., 2016) in detail (Table 1).
We named C. molestiformis as 'Ga-Neun-Ta-Rae-Sa-Cho' in Korean. It was given as the overall appearance is slimmer than C. maackii (Ta-Rae-Sa-Cho).

\section{A key of Carex molestiformis and related taxa}

1. Staminate at upper portion, bracts leaf-shaped.

C. neurocarpa 괭이사초

1. Staminate at lower portion. bracts inconspicuous, scalelike, or setaceous.

2. Spikes more than 10 in each inflorescence, pistillate scale ovate …………………. C. maackii 타래사초

2. Spikes less than 10 in each inflorescence, pistillate scale lanceolate

3. Less than 5 veins on perigynium adaxially, perigynium width 1.2-2 mm. …………... C. scoparia 한석사초

3. 6-9 veins on perigynium adaxially perigynium width 2.6-3.4 mm. …… C. molestiformis 가는타래사초

\section{Discussion}

\section{Molecular systematic analyses of three DNA barcode loci}

We analyzed and compared the sequences of $C$. moelstiformis 
Table 2. Information and sequences of primer used in this study.

\begin{tabular}{cc}
\hline \hline Primer & Sequence $\left(5^{\prime}-3^{\prime}\right)$ \\
\hline$m a t \mathrm{~K} 110 \mathrm{~F}$ & TCAATGGTTCTATCGAATCTGT \\
$m a t \mathrm{~K} 889 \mathrm{R}$ & GAATAGCTTTACCTTGATGTCG \\
$n d h \mathrm{~F} 481 \mathrm{~F}$ & CTGATAGGGTTTTGGTTTACAC \\
$n d h \mathrm{~F} 1211 \mathrm{R}$ & GACAGTGTACCCAATAAAAAGG \\
ITS $5 \mathrm{~F}$ & GGAAGTAAAAGTCGTAACAAGG \\
ITS $4 \mathrm{R}$ & TCCTCCGCTTATTGATATGC \\
\hline
\end{tabular}

Table 3. Comparison of partial sequences of cpDNA matK gene used in this study.

\begin{tabular}{|c|c|}
\hline Taxa & Sequences (partial matK, $630 \mathrm{bp}$ ) \\
\hline C. maackii & $\begin{array}{l}\text { TATGATATTAAATCTAGTTTAATACTTGTGAAACGCTTAATTATTCGAATCTATCAATCGAATTTTTTGATGAA } \\
\text { TTCGGTTATTCAAAACTGTAACCAAAATCAAATTAATGAGTACAACCGCTTTTTTTATGCTCATTTTTTTTCT } \\
\text { CAGATGATATCTGAGGGTTTTGGTTTTGTTGTAGAAATTCCATTCTCCTTTAGATTTTTATTTTCCTCCTCTA } \\
\text { AAAAAAAAATATCAAAATTGCAAGATTTACGATCTATTCATTCAATATTTTCTTTTTTAGAGGACAAATTTA } \\
\text { TTATTTAAATAATGTATTGGATATATTAATACCTTATCCTGTCCATTTTGAAATCTTAGTTCAAATCCTTCAATG } \\
\text { CTGGATCCAAGATATTTCTTCTTTGCATTTATTACGATTTTTTCTCTCCGATCATTCTAATTCGAATAGTATCAT } \\
\text { TATTTCAAAGAAATCGGTTTCTATATTCTCAAAAGAAAATATAAGACTCTCTCGTTTCTTATATAATTCTTATG } \\
\text { TATCAGAATATGAGTTTTTATTCCTGTTTTTCATAAAAAATCGTCTTGTTTACGATTAAGATCTTTTATAAGC } \\
\text { TTTCTTGAAAGAATTTACTTCTATGGAAAAATAGAACAT }\end{array}$ \\
\hline C. scoparia & $\begin{array}{l}\text { TATGATATTAAATCTAGTTTAATACTTGTGAAACGCTTAATTATTCGAATCTATCAATCGAATTTTTTGATGAA } \\
\text { TTCGGTTATTCAAAACTGTAACCAAAATCAAATTAATGAGTACAACCGCTTTTTTTATGCTCATTTTTTTTCT } \\
\text { CAGATGATATCTGAGGGTTTTGGTTTTGTTGTAGAAATTCCATTCTCCTTTAGATTTTTATTTTCCTCCTCTA } \\
\text { AAAAAAAAATATCAAAATTGCAAGATTTACGATCTATTCATTCAATATTTTCTTTTTTAGAGGACAAATTTTA } \\
\text { TTATTTAAATAATGTATTGGATATATTAATACCTTATCCTGTCCATTTTGAAATCTTAGTTCAAATCCTTCAATG } \\
\text { CTGGATCCAAGATATTTCTTCTTTGCATTTATTACGATTTTTTCTCTTCGATCATTCTAATTCGAATAGTATCAT } \\
\text { TATTTCAAAGAAATCGGTTTCTATATTCTCAAAAGAAAATATAAGACTCTCTCGTTTCTTATATAATTCTTATG } \\
\text { TATCAGAATATGAGTTTTTATTCCTGTTTTTTCATAAAAAATCGTCTTGTTTACGATTAAGATCTTTTATAAGC } \\
\text { TTTCTTGAAAG } \underline{A} \text { ATTTACTTCTATGGAAAAATAGAACAT }\end{array}$ \\
\hline C. molestiformis & $\begin{array}{l}\text { TATGATATTAAATCTAGTTTAATACTTGTGAAACGCTTAATTATTCGAATCTATCAATCGAATTTTTTGATGAA } \\
\text { TTCGGTTATTCAAAACTGTAACCAAAATCAAATTAATGAGTACAACCGCTTTTTTTATGCTCATTTTTTTTCT } \\
\text { C A G AT G ATAT C T G A G G G T T T T G G T T T T G T T G T A G A A AT T C C AT T C T C C T T T A G _ _ _ - - } \\
\text { ATTTTCCTCCTCTAAAAAAAAAATATCAAAATTGCAAGATTTACGATCTATTCATTCAATATTTTCTTTTTTAG } \\
\text { AGGACAAATTTTATTATTTAAATAATGTATTGGATATATTAATACCTTATCCTGTCCATTTTGAAATCTTAGTTC } \\
\text { AAATACTTCAATGCTGGATCCAAGATATTTCTTCTTTGCATTTATTACGATTTTTTCTCTTCGATCATTCTAAT } \\
\text { TCGAATAGTATCATTATTTCAAAGAAATCGGTTTCTATATTCTCAAAAGAAAATATAAGACTCTCTCGTTTCT } \\
\text { TATATAATTCTTATGTATCAGAATATGAGTTTTATTCCTGTTTTTCATAAAAAATCGTCTTGTTTACGATTAA } \\
\text { GATCTTTTATAAGCTTTCTTGAAAGAATTTACTTCTATGGAAAAATAGAACAT }\end{array}$ \\
\hline
\end{tabular}

cpDNA, chloroplast DNA.

with its related species from three different DNA barcode regions including cpDNA matK, $n d h \mathrm{~F}$ and nrDNA ITS. Three representative specimens of $C$. maackii, $C$. scoparia, $C$. molestiformis were used for molecular systematic analysis. We extracted total DNA according to $2 \times$ CTAB DNA extraction method (Doyle and Doyle, 1987), and 3 regions of DNA (cpDNA matK, cpDNA ndhF, nrDNA ITS region) were amplified and sequenced by the previously published method, respectively (Kim and Kim 2011, 2018).

Primers for cpDNA matK and $n d h \mathrm{~F}$ were designed by the previously published chloroplast genome data of $C$. neurocarpa (KU238086.1) (Sohn et al., 2015). And for the nrDNA ITS region, we used the universal primers (ITS5F, ITS4R) (White et al., 1990). Genious v.7.1.9 was used for analyzing the sequenced data. Information for each primer which were used in this study are presented in Table 2.

Based on the sequenced data, we obtained $630 \mathrm{bps}$ in matK, $585 \mathrm{bps}$ in $n d h \mathrm{~F}$, and $610 \mathrm{bps}$ in ITS region, and we compared these three DNA barcode loci sequences in part (Tables 3-5).

Firstly, in $630 \mathrm{bps}$ of matK sequences, 3 single nucleotide polymorphic (SNP) sites were found including $6 \mathrm{bp}$ deletion (ATTTTT) in $C$. molestiformis. In $n d h \mathrm{~F}$ region, $5 \mathrm{SNP}$ sites were identified. And in ITS region, 12 SNP sites from ITS1 and 15 SNP sites from ITS2 were found although 5.8S region 
Table 4. Comparison of partial sequences of cpDNA $n d h \mathrm{~F}$ gene used in this study.

\begin{tabular}{|c|c|}
\hline Taxa & Sequences (partial $n d h \mathrm{~F}, 585 \mathrm{bp}$ ) \\
\hline C. maackii & $\begin{array}{l}\text { ACTAATCGTGTAGGCGATTTTGGTTTATTATTAGGAATTTTAGGTTTTTATTGGATAATTGGTAGTTTCGAATT } \\
\text { CCGAGATTTATTTGAAATAACTAATAATTTAATCCAAAAA_AATGGACTAAATTCTTTATTGACTACTTTATGT } \\
\text { ACCTTTTTATTATTTGTTGGTGCAATTGCTAAATCCGCACAATTCCCACTTCATATATGGTTACCTGATGCCAT } \\
\text { GGAAGGACCCACCCCTATTTCTGCTCTTATACACGCTGCTACCATGGTAGCAGCAGGGGTTTTTCTTGTAG } \\
\text { CTCGACTCTTTCCTCTTCTCTCAATAACATCTAATATAATGCATATTATTTCTTCAAATAGGTTTAATAACATTAT } \\
\text { TATTAGGAGCTACTTTGGCTCTTGCTCAAATAGACATTAAGAGAAGTTTAGCCTATTCTACAATGTCTCAAT } \\
\text { TGGGTTACATTATACTAGCTTTAGGTATAGGTTCGTCTCGAACCGCTTTATTTCATTGATTACCCATGCTTAC } \\
\text { TCTAAGGCTTTATTGTTTTTAGGATCTGGATCTATTATTCATTCAATGGAACCTGTTGTTGGATATTCACCG }\end{array}$ \\
\hline C. scoparia & $\begin{array}{l}\text { ACTAATCGTGTAGGCGATTTTGGTTTATTATTAGGAATTTTAGGTTTTTATTGGATAATTGGTAGTTTTGAATT } \\
\text { CCGAGATTTATTTGAAATAACTAATAATTTAATCCAAAAAGATGGACTAAATTCTTTATTGACTACTTTATGT } \\
\text { ACCTTTTTATTATTTGTTGGTGCAATTGCTAAATCCGCACAATTCCCACTTCATATATGGTTACCTGATGCCAT } \\
\text { GGAAGGACCCACCCCTGTTTCTGCTCTTATACACGCTGCTACCATGGTAGCAGCAGGGGTTTTTCTTGTAG } \\
\text { CTCGACTCTTTCCTCTTCTCTCAATAACATCTAATATAATGCATATTATTTCTTCCATAGGTTTAATAACATTAT } \\
\text { TATTAGGAGCTACTTTGGCTCTTGCTCAAATAGACATTAAGAGAAGTTTAGCCTATTCTACAATGTCTCAAT } \\
\text { TGGGTTACATTATACTAGCTTTAGGTATAGGTTCGTCTCGAACCGCTTTATTTCATTTGATTACCCATGCTTAC } \\
\text { TCTAAGGCTTTATTGTTTTTAGGATCTGGATCTATTATTCATTCAATGGAACCTGTTGTTGGATATTCACCG }\end{array}$ \\
\hline C. molestiformis & $\begin{array}{l}\text { ACTAATCGTGTAGGCGATTTTGGTTTATTATTAGGAATTTTAGGTTTTTATTGGATAATTGGTAGTTTTGAATT } \\
\text { CCGAGATTTATTTGAAATAACTAATAATTTAATCCAAAAA_AATGGACTAAATTCTTTATTGACTACTTTATGT } \\
\text { ACCTTTTTATTATTTGTTGGTGCAATTGCTAAATCCGCACAATTCCCACTTCATATATGGTTACCTGATGCCAT } \\
\text { GGAAGGACCCACCCCTGTTTCTGCTCTTATACACGCTGCTACCATGGTAGCAGCAGGGGTTTTTCTTGTAG } \\
\text { CTCGACTCTTTCCTCTTCTCTCAATAACATCTAATATAATGCATATTATTTCTTCCATAGGTTTAATAACATTAT } \\
\text { TATTAGGAGCTACTTTGGCTCTTGCTCAAATAGACATTAAGAGAAGTTTAGCCTACTCTACAATGTCTCAAT } \\
\text { TGGGTTACATTATACTAGCTTTAGGTATAGGTTCGTCTCGAACCGCTTTATTTCATTTGATTACCCATGCTTAC } \\
\text { TCTAAGGCTTTATTGTTTTTAGGATCTGGATCTATTATTCATTCAATGGAACCTGTTGTTGGATATTCACCG }\end{array}$ \\
\hline
\end{tabular}

cpDNA, chloroplast DNA.

Table 5. Comparison of sequences of nrDNA ITS region used in this study.

\begin{tabular}{|c|c|}
\hline Taxa & Sequences (partial 610 bps ITS regions including parenthesized 5.8S rRNA region) \\
\hline C. maackii & 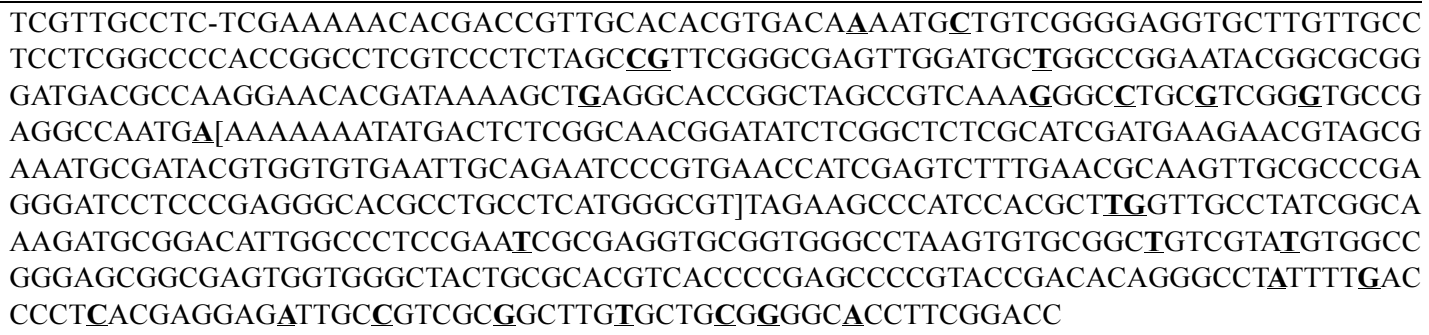 \\
\hline C. scoparia & 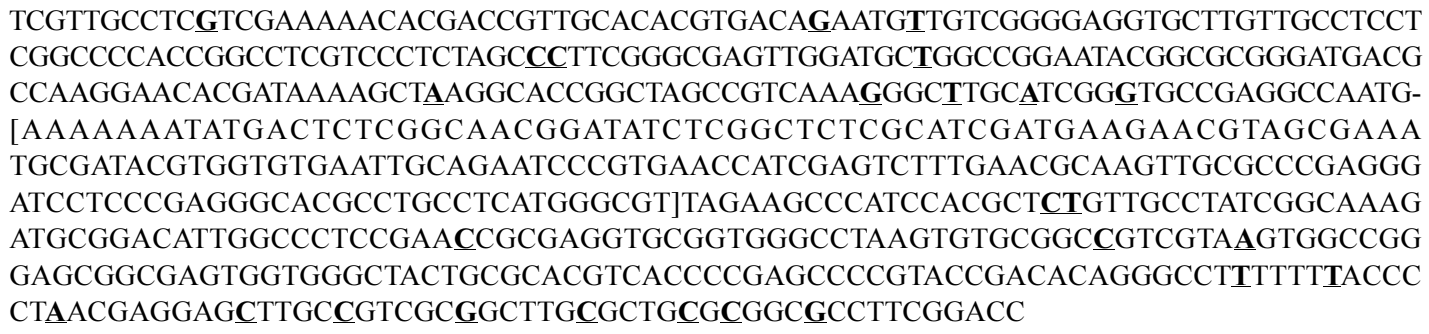 \\
\hline C. molestiformis & 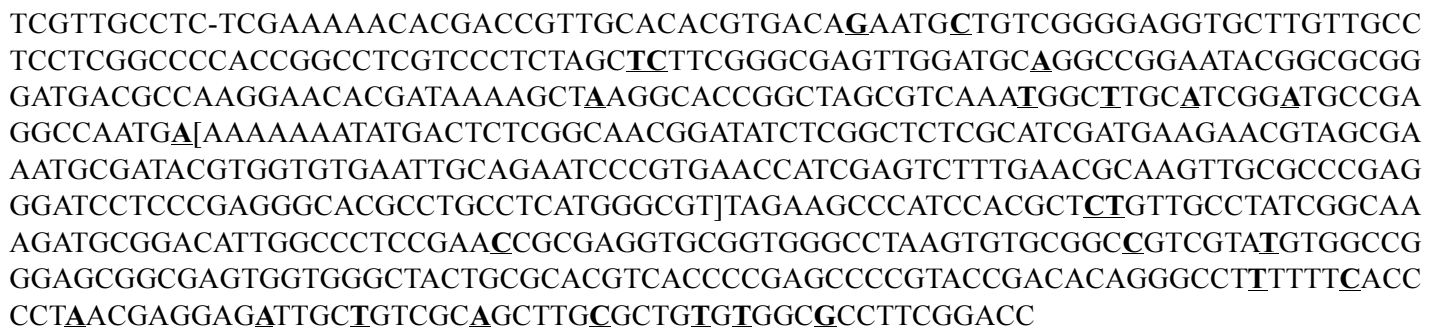 \\
\hline
\end{tabular}


Table 6. Information of sequence length and their sequence divergence.

\begin{tabular}{|c|c|c|}
\hline Region & Sequence length (bp) & Different sequences (\%) \\
\hline matK & 630 & 3 (1.43), 6 bp deletion \\
\hline$n d h \mathrm{~F}$ & 585 & $5(0.85)$ \\
\hline ITS1 & 222 & $12(5.41)$ \\
\hline $5.8 \mathrm{~S}$ rRNA & 166 & - \\
\hline ITS2 & 222 & $15(6.76)$ \\
\hline
\end{tabular}

Table 7. Comparison of single nucleotide polymorphisms and insertion/deletions in this study.

\begin{tabular}{llccc}
\hline \multicolumn{1}{c}{ Taxa/matK } & $201-206$ & 360 & 416 & 603 \\
\hline C. maackii & ATTTTT & $\mathrm{C}$ & $\mathrm{C}$ & $\mathrm{A}$ \\
C. scoparia & ATTTTT & $\mathrm{C}$ & $\mathrm{T}$ & $\mathrm{G}$ \\
C. molestiformis & Deletion & $\mathrm{A}$ & $\mathrm{T}$ & $\mathrm{A}$ \\
\hline
\end{tabular}

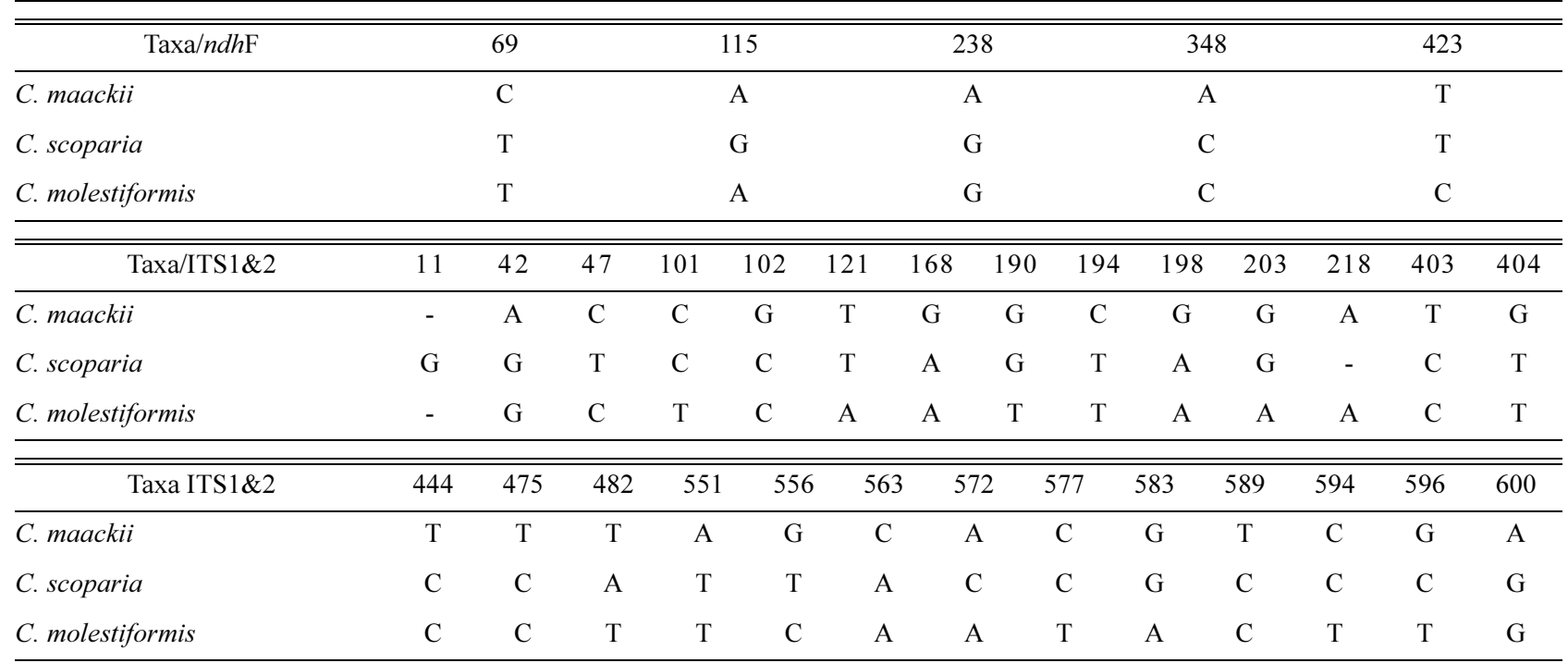

was consistent (Table 6). The sequence difference ratios were various from $0.85 \%$ in $n d h F$ to $6.76 \%$ in ITS2 (Table 6). Especially, 8 SNPs sites including 1 in matK region, 1 in $n d h \mathrm{~F}$ region and 6 in ITS region were determined as the speciesspecific markers for C. molestiformis (Table 7).

Through these analyses, we found several obvious SNPs data in 3 representative DNA barcode loci which were able to distinguish $C$. molestiformis from related species. Furthermore, it is possible to be applied as molecular markers not only for sect. Ovales but also for genus Carex.

\section{Habitat comparison}

C. molestiformis is an endemic to the southern part of United States (Reznicek and Rothrock, 1997). Comparing the climatic conditions of native habitat with the collection site in Korea (Byeokparyeong), the physiological conditions were very similar except the temperature (Peel et al., 2007). Although there are little differences of temperature $\left(1.6^{\circ} \mathrm{C}\right.$ in spring season, $1.05^{\circ} \mathrm{C}$ in summer season) (Missouri Climate Center, 2011; Korea Meteorological Administration, 2019), It is dry and composed of sun-rich grassland at the first discovered site which is nearly same climate condition as its native habitat. And it is supposed that both areas would be good to adapt for the plants of sect. Ovales to grow (Mastrogiuseppe et al., 2002).

C. molestiformis is an endemic species in the southern part of the United States, and this is the first report which has been discovered from outside of the United States. Therefore, it is highly supposed that this species has been introduced directly from the United States although its route of introduction is not clearly certain. There have been several international events recently such as the Winter Oylmpic Game and Para-olympic game at Pyeongchang (Park, 2018), it is possible that this species was introduced through transportations from abroad or by foreign visitors during those international events. 
When we firstly discovered this species at the natural habitat, those individuals were grown in patterns of several clumps which were not broadly distributed. And we supposed that the species was introduced massively because of the similarity of habitat. But when we investigated the living circumstance of its habitat recently, we recognized that this species has spread more widely along the roadside, and the number of individuals has been increased in the meadows. Then we would like to suggest that it is necessary to manage this naturalized species consistently.

The further investigation and study on the distribution of unrecorded plants including Carex should be needed to preserve biodiversity in the Korean Peninsula, especially in the Baekdudaegan area.

ORCID: Seungwon KO 0000-0002-4354-3596; Sang Deog SHIM; Jong Young HYUN 0000-0002-6782-1319; Joo-Hwan KIM 0000-0002-1248-9152

\section{Acknowledgments}

We are grateful to Mr. Gyeong-Ryeol Byun and Mr. YoungHo Jeon who have found this species firstly and helped to collect them, and Dr. Chang-Young Yoon who have given advice and discussed about this species. This study was supported by the Korea National Arboretum's project 'Securing diversity of plant seeds for ex situ conservation (KNA-20-C23 )' and we thank for the support.

\section{Conflict of Interest}

The authors declare that there are no conflicts of interest.

\section{Literature Cited}

Cheon, K.-S., K.-S. Chung, H.-T. Im and K.-O. Yoo. 2014. A newly naturalized species in Korea: Carex scoparia Schkuhr ex Willd. var. scoparia (Cyperaceae). Korean Journal of Plant Taxonomy 44: 247-249.

Doyle, J. J. and J. L. Doyle. 1987. A rapid DNA isolation procedure for small quantities of fresh leaf tissue. Phytochemical Bulletin 19: 11-15.

Cho, Y. H., J. H. Kim and S. H. Park. 2016. Grasses and Sedges in
South Korea. Geobook Press, Seoul, 527 pp. (in Korean) Kim, D.-K. and J.-H. Kim. 2011. Molecular phylogeny of tribe Forsythieae (Oleaceae) based on nuclear ribosomal DNA internal transcribed spacers and plastid DNA trnL-F and $m a t K$ gene sequences. Journal of Plant Research 124: 339-347.

Kim, J. S. and J.-H. Kim. 2018. Updated molecular phylogenetic analysis, dating and biogeographical history of the lily family (Liliaceae: Liliales). Botanical Journal of the Linnean Society 187: 579-593.

Korea Meteorological Administration. 2019. Climate of Jeongseon-gun. Retrieved Jul. 2, 2020, available from https:// data.kma.go.kr.

Mastrogiuseppe, J., P. E. Rothrock, A. C. Dibble and A. A. Reznicek. 2002. Carex L. section Ovales Kunth. In Flora of North America North of Mexico. Vol. 23. Magnoliophyta: Commelinidae (in part): Cyperaceae. Flora of North America Editorial Committee (ed.), Oxford University Press, New York. Pp. 332-378.

Missouri Climate Center. 2011. Climate of Missouri. Retrieved Jul. 2, 2020, available from http://climate.missouri.edu/.

Oh, Y. C. 2006. Korean Caricoideae of Cyperaceae. Sungshin Women's University Press, Seoul, 404 pp. (in Korean)

Park, C. H. 2018. Analysis of the impact of the Pyeongchang Winter Olympics on Korean tourism. Korean Tourism Polish 71: 18-23. (in Korean)

Peel, M. C., B. L. Finlayson and T. A. McMahon. 2007. Updated world map of the Köppen-Geiger climate classification. Hydrology and Earth System Sciences 11: 1633-1644.

Reznicek, A. A. 1993. Revision of Carex section Ovales (Cyperaceae) in Mexico. Contributions from the University of Michigan Herbarium 19: 97-136.

Reznicek, A. A. 1990. Evolution in sedges (Carex, Cyperaceae). Canadian Journal of Botany 68: 1409-1432.

Reznicek, A. A. and P. E. Rothrock. 1997. Carex molestiformis (Cyperaceae), a new species of section Ovales from the Ozark Mountain region. Contributions from the University of Michigan Herbarium 21: 299-308.

White, T. J., T. Bruns, S. Lee and J. Taylor, 1990. Amplification and direct sequencing of fungal ribosomal RNA genes for phylogenetics. In PCR Protocols: A Guide to Methods and Applications. Innis M. A., D. H. Gelfand, J. J. Sninsky and T. J. White (eds.), Academic Press, San Diego, CA. Pp. 315-322. 


\section{한반도 신귀화식물: 가는타래사초 (사초과) \\ 고승원 $^{\dagger} \cdot$ 심상득 $^{\dagger} \cdot$. 현종영 · 김주환 ${ }^{*}$ \\ 가천대학교 생명과학과, ${ }^{1}$ 우리식물연구소}

적 요: 국내 미기록종 가는타래사초(Carex molestiformis Reznik and Rothrock)를 강원도 평창군 벽파령 일대 에서 처음으로 발견하였다. 본 분류군의 원산지는 북아메리카 미국의 남부지역(Missouri, Oklahoma, Arkansas등 11개 주)으로, 자생지에서는 주로 개활지나 강둑, 범람원 등에서 무리지어 밀생한다. 타래사초절 (sect. Ovales)에 속하며, 자웅성 소수를 갖는 다년생 초본으로, 한 화서에 달리는 소수의 수가 2-4개로 적고, 과낭의 폭이 2.6-3.4 mm로 넓으며, 과낭 배면의 맥이 6-9개로 많아 국내에 자생하는 근연종인 타래사초 $(C$. maackii Maxim.) 및 귀화종인 한석사초(C. scoparia)와 명확히 구별된다. 국명은 본 분류군이 형태적으로 타 래사초와 유사하며, 식물체가 전체적으로 가늘어 '가는타래사초'로 신칭하였고, 분류군에 대한 기재문, 화상 자료 및 도해 그리고 유사종에 대한 검색표를 제시하였다. 또한, 가는타래사초와 근연종의 유전적 차이를 확 인하고자 3 개(chloroplast DNA $m a t \mathrm{~K}, n d h \mathrm{~F}$, nuclear ribosomal DNA internal transcribed spacer) DNA barcode 지역의 부분 염기서열을 비교하여, 총 8 개의 가는타래사초의 종특이적 단일염기다형성(single nucleotide polymorphisms)을 확인하였다.

주요어: 미기록종, 가는타래사초, 타래사초절, 사초과 